$R^{2}=0.31$ ). Consequently, with daily mean temperatures included in the thermoneutral zone, DMI of a good quality LU hay was slightly reduced proportionally to the maximum difference registered in daily temperatures $\left(T_{\mathrm{a}}-T_{\mathrm{i}}\right)$.

\section{Ingestion volontaire, taille des particules de digesta et poids des compartiments gastriques chez 4 types de taurillons.} EH Amouche, AG Deswysen, P Schyns (Université catholique de Louvain, faculté des sciences agronomiques, unité de génétique, place Croix-du-Sud, 2 (bte 14), 1348 Louvain-la-Neuve, Belgique)

L'objectif de ce travail était de mesurer le niveau d'ingestion volontaire, la distribution de la taille des particules de digesta, le poids des compartiments gastriques, ainsi que les performances de croissance de 4 types biologiques de taurillons.

Trente-neuf taurillons: 11 Pie-Noir (PN), 10 Pie-Rouge (PR), 9 croisés Pie-Noir $x$ Blanc-BleuBelge (CPN) et 8 croisés Pie-Rouge $x$ BlancBleu-Belge (CPR), furent suivis au cours de leur croissance de 7 à 12 mois (âge d'abattage). Ils étaient répartis selon leur âge en groupes de 3 à 5 taurillons, et logés dans des box d'une même étable sur une litière de paille. Ils reçurent à volonté du concentré $(87 \%$ MS, $15 \%$ MAT, $16 \%$ cellulose brute), de la paille et de l'eau fraîche. L'ingestion volontaire individuelle de concentré (IV) fut mesurée entre 7 et 12 mois d'âge par un système électromagnétique de portillons Calan. Des échantillons de digesta furent prélevés la veille de l'abattage au niveau du rectum, et après l'abattage au niveau du réticulo-rumen (RR), omasum $(\mathrm{Om})$ et abomasum $(\mathrm{Ab})$. La distribution de la taille des particules de digesta (DTPD) fut déterminée par tamisage sous eau. Les compartiments gastriques ( $R R, O m$ et $A b$ ) furent pesés pleins et vides.

L'IV journalière de concentré de 7 à 12 mois ne diffère pas significativement $(P=0,11)$ entre les 4 types biologiques de taurillons respectivement 81 (PN), 80 (PR), 76 (CPN) et 77 (CPR) g $\mathrm{MS} / \mathrm{kgP} 0,75$. En revanche, une différence significative est observée pour le gain quotidien moyen de 7 à 12 mois $(P=0,001)$ et le PV à l'abattage $\left(P=0,03 ; 486^{a}(\mathrm{PN}), 509^{\mathrm{ab}}(\mathrm{PR}), 534^{\mathrm{b}}(\mathrm{CPN})\right.$, $498^{a}$ (CPR) kg). La DTPD et le poids des compartiments gastriques (RR, Om, Ab) pleins ne présentent aucune différence significative entre les 4 types biologiques. Seuls les poids du RR vide et de l'ensemble des compartiments gastriques vides sont significativement $(P=0,005$ et $P=0,006$ ) supérieurs chez les taurillons $P N$, respectivement 9,08 et $13,65 \mathrm{~kg}$ comparés aux PR $(8,06$ et $12,24 \mathrm{~kg})$, CPN $(8,12$ et $12,45 \mathrm{~kg})$ et CPR $(7,58$ et $11,47 \mathrm{~kg})$. Cette supériorité de poids et sans doute de la taille de l'orifice réticulo-omasal chez les PN pourrait expliquer leur DTPD supérieure, quoique non significative.

\section{The influence of clenbuterol and pro- pranolol on lipid mobilization and food intake in dairy cows. $N$ Bareille, $P$ Faver- din (INRA, Station de Recherches sur la Vache Laitière, Saint-Gilles, 35590 L'Her- mitage, France)}

The objective of this experiment was to show whether the action of $\beta_{2}$-adrenoceptors that modulate the mobilization of adipose tissues also has an influence on dry matter intake of lactating dairy cows, and if so, whether lipid nutriments can explain this response.

$A \beta_{2}$-agonist, clenbuterol $(13.3 \mathrm{ng} / \mathrm{kg} / \mathrm{min})$ or a $\beta$-blocker, propranolol $(8.8 \mu \mathrm{g} / \mathrm{kg} / \mathrm{min})$ infused iv over a 4-h period were compared with a lipid emulsion (4 Mcal of NE of Endolipide $20 \%$ ) or a saline control. The 4 dairy cows in mid-lactation ( $34 \mathrm{~kg}$ of milk/d) were assigned to these 4 treatments on alternate days in a $4 \times 4$ latin square design with 3 replications. Two trials were carried out: in the first, perfusions were performed at night $(03.00$ to $07.00 \mathrm{~h})$, and in the second, perfusions were performed in the morning during the main meal (08.00 to $12.00 \mathrm{~h}$ ). Response on food intake was continuously recorded, while metabolic parameters were studied during the third latin square of each trial. Dairy cows were fed a mixed diet of maize silage $(70 \%)$ and concentrate $(30 \%)$ offered ad libitum twice daily after milking at 08.00 and $18.00 \mathrm{~h}$.

The results of the 2 trials were similar. In both trials, clenbuterol reduced dry matter intake by about $8 \%$ on the day of perfusion $(-1.75$ and $-2.49 \mathrm{~kg} \mathrm{DM}$ for trials 1 and 2, respectively) whereas propranolol and lipid control had no significant effect. Reduction of food intake induced by clenbuterol was delayed (2-4 $\mathrm{h}$ after the end of perfusion) and remained significant on the next day post-treatment $(-1.07$ and $-1.44 \mathrm{DM}$ for trials 1 and 2, respectively). The kinetics of plasma- 
free fatty acids were similar during clenbuterol or lipid control treatment; concentrations were high during perfusions (between 200 and $300 \mu$ eq/l) and returned to basal levels within $2 \mathrm{~h}$. Propranolol did not succeed in decreasing spontaneous lipolysis, even when perfused at night.

The results indicate that clenbuterol decreases intake and increases lipomobilization, but there is no clear indication of a direct influence of lipomobilization and lipid nutrients on intake.

\section{Effect of a concentrate supply, ingested or introduced in the rumen with or without increase of fill, on the daily kine- tics of the intake of hay by cows. $\mathrm{R}$ Bau- mont, O Daveau, C Perpere (INRA-Theix, Station de Recherches sur la Nutrition des Herbivores, 63122 Saint-Genès-Champa- nelle, France)}

In ruminants, ingestion of feed induces both oropharyngeal stimuli, and ruminal (mechanical and chemical) stimuli. This experiment was designed to separate the 3 types of stimuli and to quantify their role in the control of intake. Four dry rumen fistulated cows were offered hay ad libitum (voluntary intake of $8.0 \mathrm{~kg} \mathrm{DM}$ ) at $9 \mathrm{am}$. According to a 3 times repeated latin square design, the cows received the following treatments every $4 \mathrm{~d}$ : control (hay only); a barley meal (2.7 kg DM) ingested (I) before the daily distribution of hay; the same amount of barley introduced into the rumen (R) after mixing with $4 I$ of artificial saliva; and the meal introduced into the rumen but without increasing fill (RWIF). The last treatment was done by removing 6.2 I of rumen content before introducing the concentrate. The kinetics of intake and feeding behaviour were recorded throughout the experiment. The rumen juice was sampled for $\mathrm{pH}$, osmotic pressure and VFA measurements every 30 min on the treatment day, the day before and the day after during the second latin square. Oropharyngeal stimuli induced by the ingestion of the concentrate played an important role in the short-term control of intake (reduction of hay intake during the treatment day of $12.8 \%$ for I vs $6.8 \%$ for $\mathbf{R}$ ). With I, the intake was significantly reduced during the hour following distribution of hay $(-19 \%)$ and during the afternoon period $(-18 \%)$. With $R$, intake was only significantly reduced during the afternoon period $(-12 \%)$. Oropharyngeal stimuli induced by the concentrate were also of importance for the control of hay intake the day after (reduction of hay intake of $11 \%$ for I vs $3.2 \%$ for $\mathbf{R}$ ). The increase of rumen fill due to the concentrate also acted as a satiety signal (reduction of hay intake during the treatment day of $6.8 \%$ for $\mathbf{R}$ vs $2.2 \%$ for RWIF). Chemical modifications due to the ruminal degradation of the concentrate $\mathrm{pH}$ lowered from 0.4 units and VFA concentration increased by $14 \%$ $3 \mathrm{~h}$ after the concentrate meal) had little effect on the short-term satiation process.

\section{Effects of nitrogen fertilization and soy- bean meal supplementation on herbage intake by grazing dairy cows. $\mathrm{R}$ Dela- garde, JL Peyraud, L Delaby (INRA, Sta- tion de Recherches sur la Vache Laitière, 35590 Saint Gilles, France)}

Two levels of $\mathrm{N}$ fertilization $(0(\mathrm{LN})$ and $60(\mathrm{HN}) \mathrm{kg}$ $\mathrm{N} /$ ha/cycle applied over 2 years) and 2 levels of soybean meal (SBM) supplementation ( 0 and $2 \mathrm{~kg}$ $\mathrm{SBM} / \mathrm{cow} / \mathrm{d}$, including $1 \mathrm{~kg}$ protected) were compared in a $4 \times 4$ latin square design using $8 \mathrm{Hol}-$ stein dairy cows. The experimental periods lasted $12 \mathrm{~d}$. The pastures were 32-d regrowths of perennial rye-grass strip-grazed at a herbage allowance of $21 \mathrm{~kg} \mathrm{OM} / \mathrm{cow} / \mathrm{d}$ (cut at $8.5 \mathrm{~cm}$ height). Individual herbage organic matter intake (HOMI) was calculated by estimating: 1) faecal output, using chromic oxide; and 2) grass digestibility (gD), from faecal N and ADF contents and pepsine-cellulase digestibility $(\mathrm{pcD})$ of grass $(\mathrm{gD}=$ $0.624+0.284 p c D+0.0165 \mathrm{~N}-0.00354$ ADF; $R^{2}=0.93 ;$ etr $=0.011$ ). Dung pats were sampled during the last $5 \mathrm{~d}$ of each period. Grazing time (GT) was automatically recorded (at least 2 $\mathrm{d} / \mathrm{cow} /$ period) and mean bite rate (BR) was estimated by visual observation during main meals (records of $2 \mathrm{~min}$ ).

Lowering $\mathrm{N}$ fertilization resulted in a decrease of herbage mass ( 1.9 vs $2.6 \mathrm{t} \mathrm{OM} / \mathrm{ha}$ ) and $\mathrm{CP}$ content (10.6 vs $17.3 \%)$ and an increase in the soluble carbohydrate content of the grass ( 15.7 to $22.1 \%$ ). HOMI (16.0 vs $18.6 \mathrm{~kg} \mathrm{OM} / \mathrm{cow} / \mathrm{d})$, digestibility ( 0.775 vs 0.808 ), fat-corrected milk (22.1 vs $24.1 \mathrm{~kg} / \mathrm{cow} / \mathrm{d}$ ) and milk protein content (27.9 vs $28.4 \mathrm{~g} / \mathrm{kg}$ ) were greatly depressed in $\mathrm{LN}$ sward compared with HN sward. GT (557 min/d) and BR ( 54 bites/min) did not vary. Bite size should therefore be reduced in LN sward. This may be related to modifications of sward structure 